\title{
An antarctic feeding triangle: defensive interactions between macroalgae, sea urchins, and sea anemones
}

\author{
Charles D. Amsler ${ }^{1, *}$, James B. McClintock ${ }^{1}$, Bill J. Baker ${ }^{2}$ \\ ${ }^{1}$ Department of Biology, University of Alabama at Birmingham, Birmingham, Alabama 35294-1170, USA \\ ${ }^{2}$ Department of Chemistry, Florida Institute of Technology, Melbourne, Florida 32901, USA
}

\begin{abstract}
A relationship between macroalgae (Phyllophora antarctica and Iridaea cordata), the sea urchin Sterechinus neumayeri, and the sea anemone Isotealia antarctica in Antarctica is described. Both macroalgal species are chemically defended against herbivory by $S$. neumayeri. Where macroalgae and urchins co-occur in the field, over $95 \%$ of the urchins use macroalgae as cover and the vast majority of available drift is held by them. Urchins collected from sites without macroalgae prefer macroalgae over other cover materials in the laboratory, suggesting that they make an active behavioral choice to cover with macroalgae when available. Macroalgal cover acts as a defense against the major sea urchin predator, I. antarctica. Algal cover significantly increases the likelihood that urchins will escape from I. antarctica because the anemones' tentacles attach to the algae, which are subsequently released by the anemone or by both the urchin and the anemone. This defense is physical as thalli from which defensive chemicals have been extracted are equally protective. Macroalgae appear to derive benefit from this relationship because fertile drift plants are retained in the photic zone where they can continue to contribute to the gene pool. The urchins also extend the effective horizontal and vertical distributions of the macroalgae, which may help sustain the range of these algal populations in periods of reduced light availability. Hence, even though the macroalgae are chemically defended from urchin herbivory, this relationship is apparently mutualistic. It benefits the sea urchins by providing a defense against their primary predator and benefits the macroalgae by helping to sustain a reproductive population.
\end{abstract}

KEY WORDS: Chemical defense - Physical defense $\cdot$ Mutualism - Macroalgae $\cdot$ Sea urchins - Sea anemones Antarctica

\section{INTRODUCTION}

Plants and animals utilize a diverse array of chemical and physical mechanisms to prevent herbivory or predation. Chemical defenses typically involve production of secondary metabolites that are toxic, distasteful, or both to potential consumers (cf. Paul 1992, Roitberg \& Isman 1992, Pawlik 1993, Eisner \& Meinwald 1995, Hay 1996, McClintock \& Baker 1997a, Faulkner 1998). Physical defenses can include the production of armor or an otherwise tough external coating, the production

\footnotetext{
·E-mail: amsler@uab.edu
}

of thorns or other physical barriers, or the production or incorporation of detachable structures (cf. Steneck \& Watling 1982, Vitt 1983, Harvell 1984, Endler 1986, Myers \& Brazely 1991). Chemical and physical defenses are not mutually exclusive and a variety of organisms utilize them in combination (e.g. Hay et al. 1994, Schupp \& Paul 1994, Mauricio \& Rausher 1997).

We have previously shown that the antarctic marine red macroalgae Iridaea cordata and Phyllophora antarctica are chemically defended against herbivory by the sea urchin Sterechinus neumayeri (Amsler et al. 1998). These macroalgal species dominate shallow benthic communities in Terra Nova Bay $\left(74^{\circ} 42^{\prime}\right.$ S) with standing wet biomass sometimes exceeding $2 \mathrm{~kg} \mathrm{~m}^{-2}$ 
(Gambi et al. 1994). They can also be the dominant macroorganisms in shallow waters at some sites near the southern limit of their distribution above $77^{\circ} \mathrm{S}$ (Zaneveld 1968) and are the only 2 non-crustose macroalgae throughout most of the year in our study area at McMurdo Sound ( $77^{\circ} \mathrm{S}$ i Miller \& Pearse 1991)

Sterechinus neumayeri is the most abundant sea urchin in shallow antarctic waters and is a major consumer in the benthic trophic web of the study area (Brey et al. 1995). This species is an omnivore that has been documented to consume microalgae, macroalgae, seal feces, carrion, and a wide variety of invertebrates (reviewed by McClintock 1994). S. neumayeri individuals cover their tests with both Iridaea cordata and Phyllophora antarctica but rarely eat them (Pearse \& Giese 1966, Miller \& Pearse 1991, McClintock 1994, Amsler et al. 1998). Many species of sea urchins are known to cover themselves with macroalgae, shells, rocks, or a variety of other objects and many explanations for this behavior have been proposed in the past (reviewed by Lawrence 1976). Dayton et al. (1970) reported on covering behavior in $S$. neumayeri from antarctic sites without macroalgae. They described field observations showing that urchins covered by branching hydroid colonies were less susceptible to capture by their major predator, a large sea anemone now called Isotealia antarctica. S. neumayeri are attacked by $I$. antarctica when a foraging urchin strays into the tentacles of an anemone. Cover materials facilitate escape by forming a detachable shield to which the anemone's tentacles first adhere and that the urchins then release (Dayton et al. 1970).

Interactions between sympatric populations are typically defined as mutualistic if both interacting species derive benefit (Boucher et al. 1982, Ricklefs 1990, Bronstein 1994). These benefits can involve: (1) protection from a predator or from the environment; (2) dispersal of spores, gametes, larvae, seeds, or other propagules; (3) transport away from unsuitable habitats; and (4) provision of energy, nutrients, or other substances necessary for growth (Boucher et al. 1982). Although a wide range of such interactions has been examined, interactions of plants and animals with the plant species deriving a reproductive benefit are particularly well documented (Bronstein 1994).

In the present report we document that, even though they are chemically defended from being consumed by the urchins, macroalgae are the actively preferred form of cover for Sterechinus neumayeri and that this covering behavior is apparently part of a mutualistic interaction between the macroalgae and urchins. It benefits the macroalgae by retaining plants in the photic zone where they continue to contribute to the gene pool and by extending their spatial distribution. It benefits the sea urchins by providing a detachable algal barrier that physically defends them from their primary predator, the sea anemone Isotealia antarctica.

\section{MATERIALS AND METHODS}

Collection sites and organisms. All organisms were collected by scuba diving from McMurdo Sound, Antarctica, in October and November, 1997 Primary collection sites in eastern McMurdo Sound included: the north and south sides of Cape Evans $\left(77^{\circ} 38^{\prime} \mathrm{S}\right.$, $\left.164^{\circ} 24^{\prime} \mathrm{E}\right)$, Little Razorback Is. (77 $\left.40^{\prime} \mathrm{S}, 164^{\circ} 31^{\prime} \mathrm{E}\right)$, Arrival Heights $\left(77^{\circ} 49^{\prime} \mathrm{S}, 164^{\circ} 39^{\prime} \mathrm{E}\right.$ ), and McMurdo Station $\left(77^{\circ} 51^{\prime} \mathrm{S}, 164^{\circ} 40^{\prime} \mathrm{E}\right.$ ). In western McMurdo Sound, 2 distinct collection sites in the Granite Harbor area $\left(77^{\circ} 01^{\prime} \mathrm{S}, 162^{\circ} 51^{\prime} \mathrm{E}\right.$ and $77^{\circ} 01^{\prime} \mathrm{S}, 162^{\circ} 49^{\prime} \mathrm{E}$ ) were utilized. The experimental organisms were maintained in and all laboratory work was conducted in flowing seawater aquaria at McMurdo Station with a temperature of $-1.5^{\circ} \mathrm{C}\left( \pm 0.5^{\circ} \mathrm{C}\right)$ and with constant illumination (natural summer photoperiod in the study area). Illumination was provided by a combination of overhead lights and indirect sunlight at a photon flux density ranging from 3 to $25 \mu \mathrm{mol}$ quanta $\mathrm{m}^{-2} \mathrm{~s}^{-1}$. Isotealia antarctica were fed freeze-dried antarctic krill Euphausia superba once per week but not less than $4 \mathrm{~d}$ before use in an experiment. Each aquarium contained a well-developed benthic microflora which the Sterechinus neumayeri appeared to consume. Under such conditions $S$. neumayeri is able to live for long periods and to develop or maintain mature gonads with viable gametes (McClintock pers. obs.)

Urchin cover transects. All urchins in $1 \mathrm{~m}$ wide transects which were oriented vertically along the sloping bottom were counted by a swimming diver. The depth range sampled varied with site topography. Estimated urchin cover was scored in 4 categories: (1) $>90 \%$ of cover material being Phyllophora antarctica; (2) $<10 \%$ of cover material being $P$. antarctica; (3) between 10 and $90 \%$ of cover material being $P$. antarctica and (4) urchins not covered by any object. Sample transects were: 5 to $15 \mathrm{~m}$ depth at the north side of Cape Evans, $\mathrm{N}=145$ urchins, bottom slope moderately steep (cf. Miller \& Pearse 1991); 3 to $30 \mathrm{~m}$ depth at Little Razorback Is., $N=310$ urchins, bottom slope very steep $\left(>45^{\circ}\right)$ up to $5 \mathrm{~m}$, with a more gradual slope above (nearly vertical cliffs were common below $25 \mathrm{~m}$ but did not begin until $>33 \mathrm{~m}$ at the spot the transect was done); and 7 to $30 \mathrm{~m}$ depth at the easternmost Granite Harbor site, $N=1144$ urchins, bottom slope very steep $\left(>45^{\circ}\right.$ ) up to $7 \mathrm{~m}$ (at which point the bottom dipped before rising again with a gradual slope). One transect was performed at each site. The percentage of urchins in each cover group was arcsine (square root) transformed to satisfy assumptions of equal variance and 
compared statistically by analysis of variance (GLM) and by a Ryan-Einot-Gabriel-Welsch (REGWQ) post hoc test (equivalent to a Ryan's Q-test) using SPSS software (SPSS Inc., Chicago, IL).

Cover choice experiments. We collected 41 urchins with their cover from Arrival Heights, a site where macroalgae do not occur, and 60 urchins covered only with Phyllophora antarctica from the north side of Cape Evans. All cover items were removed, sorted, and weighed wet. Volumes were determined by water displacement. A cover material mixture was prepared with the combined material from all 41 Arrival Heights urchins and a biomass equivalent to the $P$. antarctica from 41 of the 60 Cape Evans urchins. This mixture contained $44.2 \mathrm{~g}$ of $P$. antarctica which displaced $26 \mathrm{ml}$ of water. The mixture also contained $423.6 \mathrm{~g}$ of nonalgal cover which displaced $349 \mathrm{ml}$ of water and was comprised of $111.7 \mathrm{~g}$ of branching hydroid colonies, $30.2 \mathrm{~g}$ of sponge fragments (mostly from Homaxinella balfourensis), $94.2 \mathrm{~g}$ of invertebrate shells or shell fragments, $120.9 \mathrm{~g}$ of small rocks, and $66.6 \mathrm{~g}$ of other nonmacroalgal material (including live bivalves and sea cucumbers, fish bone, worm tubes, and unidentifiable material).

The urchins collected at Arrival Heights were divided into 4 groups of 10 for use in 4 separate choice experiments. This method that combined 10 urchins in a tank was chosen over a single animal design because of the difficulty of individually replicating the complex mixture of the non-algal cover material. Each group was placed in 2 rows down the center a flowing seawater aquarium $(1.4 \times 0.9 \times 0.15 \mathrm{~m})$ and the cover mixture was poured around but not over them. A constant irradiance of 3 to $8 \mu \mathrm{mol}$ quanta $\mathrm{m}^{-2} \mathrm{~s}^{-1}$ was provided by overhead cool white fluorescent lights. After $12 \mathrm{~h}$, the urchins had selected cover materials. Urchins with their cover were removed and the cover material from each urchin was sorted and weighed wet. For analysis, the mass of each cover item (or group) was combined for the 10 urchins in each experiment (sample size for statistical analyses $=4$ ). The percent of tank total for each cover group was calculated. These data were arcsine (square root) transformed to satisfy assumptions of equal variance and cover by algal versus nonalgal materials compared statistically by t-test using SPSS software.

Urchin escape assays. Iridaea cordata was collected from the south side of Cape Evans, Phyllophora antarctica from Little Razorback Is., and Isotealia antarctica from Arrival Heights. Sterechinus neumayeri was collected from several locations in eastern McMurdo Sound between Cape Evans and McMurdo Station. I. antarctica individuals were attached to small rocks. Half of the $S$, neumayeri individuals were allowed to cover themselves with macroalgae. Subjectively, the amount of covering algae per urchin was roughly equivalent to that observed for $P$. antarctica cover in nature and slightly less than that observed for $I$, cordata cover in nature. Urchins with or without cover were then placed next to an anemone and allowed to grip the substrate with their oral tube feet as they would during normal foraging in nature. The rock to which the anemone was attached was then gently slid toward the urchin until the edge of the urchin was directly beneath the oral disk of the anemone and, therefore, the urchin was in contact with several of the anemone's tentacles. The urchin-anemone pair was separated from the rest of the aquarium with a plexiglass partition and their interaction followed until the urchin was either free of the anemone's tentacles or had been captured and consumed. A total sample size of 20 urchins was utilized for each treatment (algal type or no-algae control) in each experiment. Anemones were offered $1 / 2$ of a freeze-dried antarctic krill (mean dry weight $=131 \mathrm{mg}$ ) 1 to $2 \mathrm{~h}$ before the experiment. If an anemone did not consume the krill, which happened very rarely, it was not used in the experiment. Anemones which consumed an urchin were not utilized again for at least $7 \mathrm{~d}$ and no anemones were used in more than 1 replicate trial for any algal type. The number of captured versus escaped urchins in each experiment was statistically compared using a Fisher's exact test (Zar 1984).

Urchin test diameters ranged from 3.0 to $4.7 \mathrm{~cm}$. Anemone oral disk diameters ranged from 6 to $11 \mathrm{~cm}$. The mean ratio of urchin test diameter to anemone oral disk diameter was the same for each treatment (cover or no cover) in each experiment ( $t$-test, $\mathrm{p}>0.05)$ and 0.52 over all experiments. Within the small range of diameter ratios used $(0.33$ to 0.66$)$, there was no significant relationship between diameter ratio and the outcome of a trial ( $t$-test, $\mathrm{p}>0.05$ ). Ratio data were arcsine (square root) transformed for statistical analyses, which were performed using SPSS software.

To determine if the secondary metabolites responsible for macroalgal defense against urchins were responsible for protecting the urchins against anemones, macroalgal thalli were extracted in $1: 1 \mathrm{CH}_{2} \mathrm{Cl}_{2}$ :methanol followed by 1:1 methanol:water. Although the volume of solvents used per unit algal biomass in the previous study (Amsler et al. 1998) should have quantitatively removed the defensive compounds, the solvents were used at even higher volumes per unit biomass in the present study to ensure complete extraction. After extraction the algae were passed through multiple changes of filtered seawater for $24 \mathrm{~h}$ and then held in flowing seawater before use in urchin escape assays. Subjectively, compared to urchins that covered with live macroalgae, the amount of extracted algae per urchin was roughly equivalent to that 
observed for Iridaea cordata and slightly less than that observed for Phyllophora antarctica.

Algal fertility survey. Phyllophora antarctica growing attached to rock and also being used as cover by urchins was collected between 7 and $10 \mathrm{~m}$ depth at Little Razorback Is. and at both locations in Granite Harbor. Plants being used as cover by urchins were also collected along the $15 \mathrm{~m}$ depth contour at each site. For each plant group at each site, 31 randomly selected plants were examined visually for the presence of cystocarps. These represent a sporophytic generation which develops directly on lateral protrusions of female gametophytes and releases spores. Cystocarps are visible because they cause the proliferations to become swollen. Iridaea cordata was found only at Cape Evans. At the time these collections were made, only 11 attached plants at $6 \mathrm{~m}$ depth and 54 drift plants being used as cover by urchins between 9 and $12 \mathrm{~m}$ depth could be located on the north side of the cape and all were examined for the presence of cystocarps, which in $I$. cordata are visible as dark, thickened regions on the blades. Percent fertility data were arcsine (square root) transformed and statistically compared using SPSS software GLM and REGWQ tests

\section{RESULTS}

We have observed Sterechinus neumayeri in nature using a wide variety of objects as cover but at sites where macroalgae co-occur with $S$, neumayeri the vast majority of urchins are covered with drift algae. In vertically oriented transects at 3 such sites, $96.5 \%$ of the urchins were using Phyllophora antarctica for $90 \%$ or more of their cover (Fig. 1). The 90\% threshold was used to expedite sampling but the vast majority of these urchins appeared to be completely covered with P. antarctica. Iridaea cordata was also present at 1 of the transect sites (Cape Evans) but was unusually rare compared to previous seasons based on observations by ourselves and others (Miller \& Pearse 1991). Urchins covered with $I$. cordata were present there but did not occur in the transect.

To determine if the apparent preference for macroalgal cover by Sterechinus neumayeri in nature represents an active choice by the urchins or merely an abundance of drift macroalgae available for cover, we determined preferences for cover in the laboratory using $S$. neumayeri individuals collected from a site where attached macroalgae do not occur and where drift macroalgae are quite rare. We allowed the cover on urchins in nature to determine the relative amounts of algal and non-algal cover to be used in the experiments and, as noted above, this resulted in a much smaller total mass and volume of Phyllophora antarc-

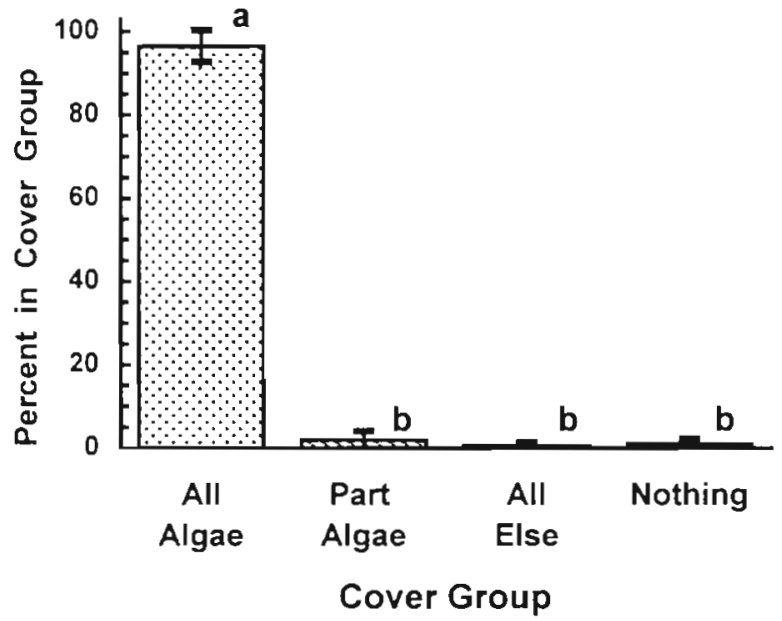

Fig. 1. Percentage of urchin Sterechinus neumayeri in nature covered with macroalgae Phyllophora antarctica versus other objects. Means \pm 1 standard deviation. See text for group definitions. Analysis of variance indicated significant differences between groups $\left(F_{3,11}=136.9, \mathrm{p}=0.0001\right)$. REGWQ post hoc test indicated that significantly more urchins were in the All Algae group than in any other $(p<0.0001)$, as indicated in the figure by letters $a$ and $b$

tica relative to non-algal material $(44.2 \mathrm{~g} P$. antarctica vs $423.6 \mathrm{~g}$ non-algal, water displacement $26 \mathrm{ml}$ for P. antarctica vs $349 \mathrm{ml}$ for non-algal). After $12 \mathrm{~h}$, the urchins had covered themselves with significantly more $(p<0.001)$ of the total available P. antarctica than of the total available non-algal cover (Fig. 2). All urchins had at least some $P$. antarctica as part of their cover. Although we did record choices of individual groups of non-algal cover, it was very rare for urchins in nature to be covered by any single non-algal cover item so no per-urchin equivalent could be established for anything but total macroalgal and total non-algal cover. Also, because the only equivalent groupings in the experiment were total macroalgal versus total nonalgal cover, the relative proportion of individual types of non-algal cover are not directly comparable with each other or with the macroalgal cover. However, percentages of tank totals of individual types of non-algal cover being held by urchins ranged only from 4.7 to $13.2 \%$ (Fig. 2), suggesting that no individual non-algal cover item was as highly preferred as the macroalgae.

In order to experimentally assess whether macroalgal cover provides protection to Sterechinus neumayeri during predation by Isotealia antarctica, we presented urchins with and without macroalgal cover to I. antarctica in an aquarium. In control treatments without macroalgal cover, 14 to 16 of the 20 urchins in each experiment were captured and consumed by I. antarctica (Fig. 3). These interactions were something of a 'tug-of-war' since an urchin would be held in place or pulled toward the anemone while the 


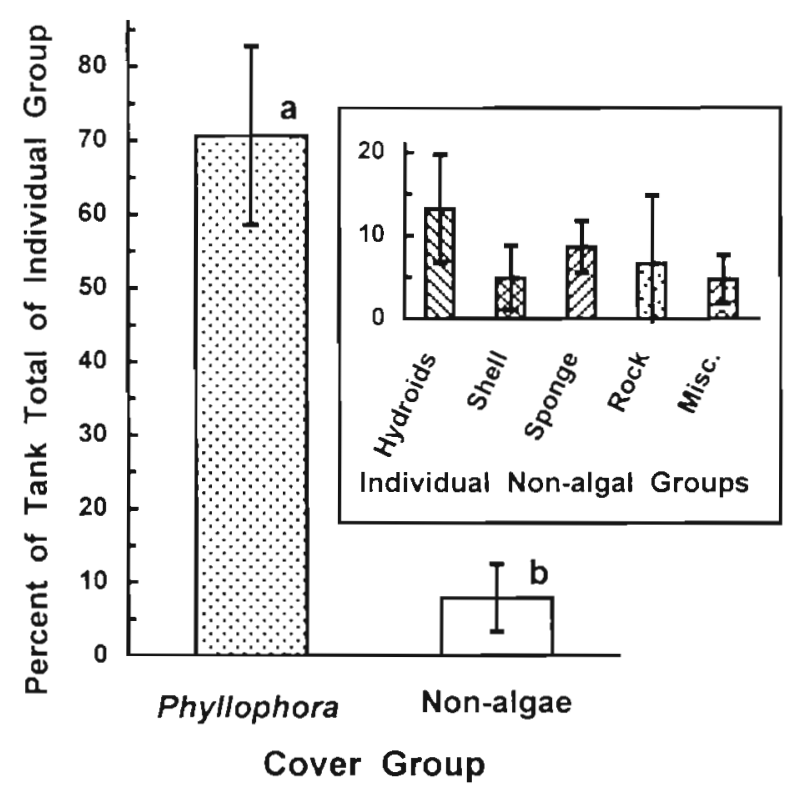

Fig. 2. Sterechinus neumayeri cover choice experiments comparing Phyllophora antarctica to non-algal cover items in the laboratory. Data expressed as means \pm 1 standard deviation of tank total of each cover group picked up by urchins in $12 \mathrm{~h}$. The 2 groups are significantly different ( $t$-test, $p<0.001$ ), as indicated on the figure by letters $a$ and $b$. Inset indicates data from individual non-algal cover groups. These data are not directly comparable with each other or with the P. antarctica data (see text)

anemone extended its body column to engulf the urchin (Fig. 4). To escape, an urchin needed to be able either to pull itself away from the tentacles completely or to pull itself far enough away so that the anemone could not extend its body column to engulf it. In the latter cases, the anemones eventually released their grip on the urchins although this sometimes took over an hour to occur. Cover with either live Phyllophora antarctica or live Iridaea cordata, however, allowed the vast majority of urchins to escape capture (only 1 of 20 urchins with each cover type were consumed; Fig. 3) and to do so quickly. The macroalgae being carried by urchins facilitated escape through 1 or both of 2 mechanisms. The anemone would first grip the macroalgae with its tentacles while initiating an attack on the urchin. Often, the urchin would release the macroalgae being gripped by the anemone and move away. The anemones never consumed the macroalgae and subsequently released their grip, allowing the algae to drift off. Alternately, the anemone would release the macroalgae before the urchin, allowing the urchin to move away with its

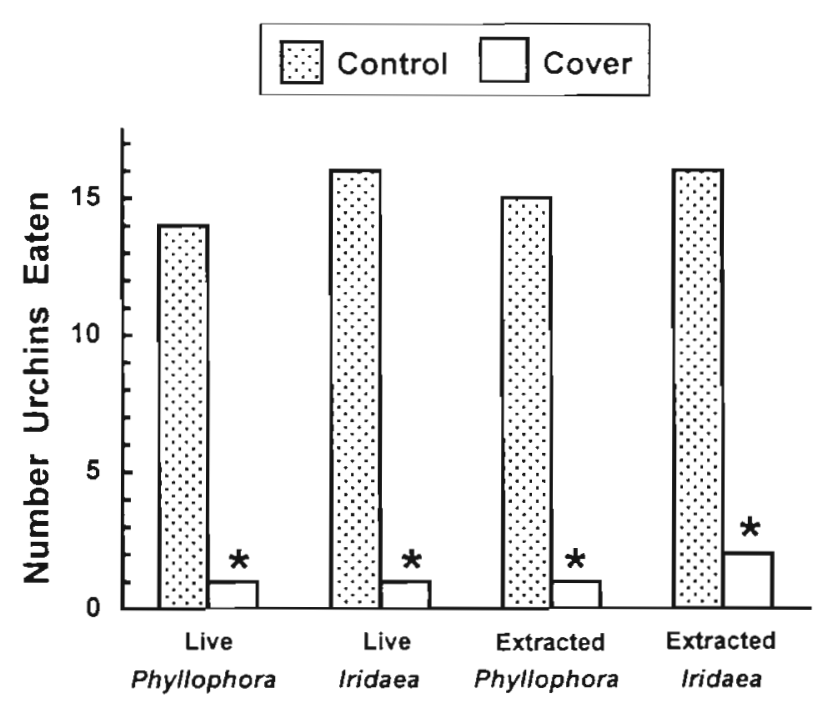

Fig. 3. Number of Sterechinus neumayeri consumed by Isotealia antarctica (of 20 total per experiment) with live and extracted macroalgae as cover versus no-cover controls. Fisher exact tests (2-tail) indicated significant differences between controls and experimental treatments in all experiments ( $p<0.00004)$, as indicated by asterisks

cover intact. I. antarctica is typically observed to initially grip any living or inert object that comes into contact with its tentacles and to subsequently release those items it does not prefer to consume (McClintock \& Baker 1997b). In the most rapid escapes, particularly where the anemone released the macroalgae before the urchin did, it is possible that the anemone did not recognize the urchin prey but the urchins were always

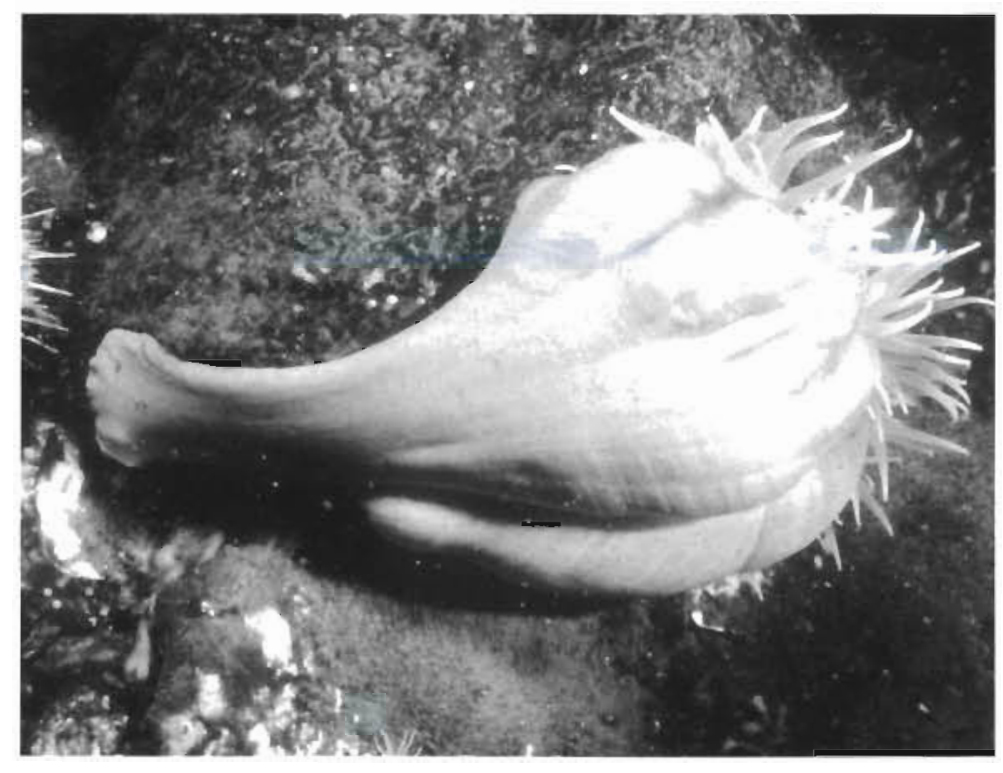

Fig. 4. Isotealia antarctica consuming Sterechinus neumayeri in nature. Extended anenome length is approximately 15 to $20 \mathrm{~cm}$ 
observed to move away from the anemone after contact. In cases where covered urchins were consumed by the anemones, it appeared that several tentacles were able to get around the algal cover and attach to the urchin directly. Most if not all macroalgae consumed by an anemone along with an urchin was subsequently regurgitated in an undigested and apparently healthy state.

To determine if the defensive compounds that prevent Sterechinus neumayeri from consuming Phyllophora antarctica and Iridaea cordata (Amsler et al. 1998 ) play a role in defending $S$. neumayeri covered by these macroalgae from predation by Isotealia antarctica, we extracted the compounds from both macroalgal species and allowed urchins to cover themselves with the extracted thalli. These extracted thalli provided the same level of protection from urchin predation as the intact thalli (Fig. 3), indicating that the defensive compounds do not serve a necessary role in allowing $S$. neumayeri to escape from $I$. antarctica.

At all sites we have observed in McMurdo Sound where attached macroalgae occur, drift macroalgae are typically much more abundant than attached plants and virtually all drift algae are used as cover by Sterechinus neumayeri. Very few, if any, drift macroalgae that were not being used as cover by urchins were observed. Since the bottom topography at most of these sites is a very steep slope, plants not retained by urchins would likely be washed out of the photic zone quickly. The plants held by $S$. neumayeri remain normally pigmented and apparently healthy (also noted by Miller \& Pearse 1991). Of much greater significance, they retain their ability to produce spores while being carried by the urchins. We sampled 3 sites where attached Phyllophora antarctica was restricted to a depth range of only 7 to $10 \mathrm{~m}$ but where drift plants on urchins were abundant over the entire depth range observed ( 3 to $40 \mathrm{~m}$ ). Of the attached plants, $76.3 \%$ were fertile (cystocarpic) compared to $63.4 \%$ of the drift plants collected in the 7 to $10 \mathrm{~m}$ depth zone (Fig. 5). At $15 \mathrm{~m}$, which was below the depth range of attached plants at these 3 sites (at least when we sampled them) but which is within the range reported for $P$. antarctica in other years and elsewhere (Miller \& Pearse 1991, Gambi et al. 1994), 44.0\% of the drift plants held by urchins were fertile. We also sampled I. cordata at the single site we were able to collect it. A few attached plants were collected at $6 \mathrm{~m}$ depth and of these, $90.9 \%$ were cystocarpic (Fig, 5). We were only able to collect drift plants, all on urchins, between 9 and $12 \mathrm{~m}$ depth. Of these, 75.9\% were fertile (Fig. 5). Plants of either species scored as non-fertile could have been male but Miller \& Pearse (1991) suggested that males are quite rare in both species in McMurdo Sound.

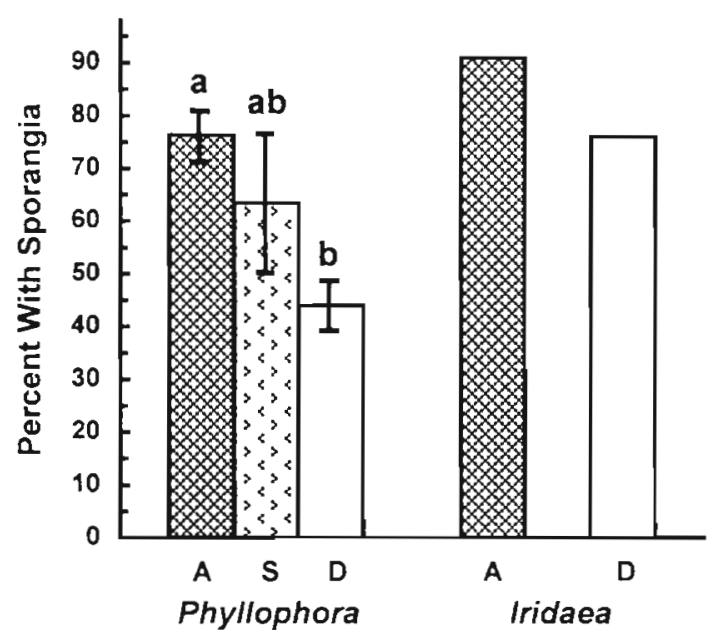

Fig. 5. Percent fertile macroalgae attached directly to the bottom and being used as cover by urchins. Means \pm 1 standard deviation for Phyllophora antarctica ( $N=3$ sites). Values at a single site for Iridaea cordata. A = attached directly to bottom. Depth range 7 to $10 \mathrm{~m}$ for $P$ antarctica and $6 \mathrm{~m}$ for $I$. Cordata. $\mathrm{S}$ = shallow macroalgae being used as cover by urchins. Depth range 7 to $10 \mathrm{~m}$ for $P$. antarctica. No shallow 1 . cordata on urchins was present $D=$ deep macroalgae being used for cover by urchins. Depth was $15 \mathrm{~m}$ for $P$. antarctica and 9 to $12 \mathrm{~m}$ for $I$. cordata. GLM indicated a significant difference between $P$. antarctica sample groups $\left(F_{2,8}=7.235, \mathrm{p}=0.025\right)$. REGWQ (alpha $<0.05$ ) showed that there was no significant difference between fertility of $P$. antarctica on urchins at 7 to $10 \mathrm{~m}$ and either attached plants or plants on urchins at $15 \mathrm{~m}$ but that attached plants and plants on urchins at $15 \mathrm{~m}$ had significantly different fertility percentages, as indicated on the figure by letters $a$ and $b$

\section{DISCUSSION}

To our knowledge, this relationship between the macroalgae Phyllophora antarctica and Iridaea cordata and the sea urchin Sterechinus neumayeri represents the first report of marine plants sustaining their reproductive output and spatial distribution through the active behavioral choice of a sympatric animal. Because this animal is also a herbivore that the plants chemically defend themselves against and because the animal benefits by being protected from its major predator, we believe this relationship represents a form of mutualism facilitated through chemical and physical defenses.

Ecological relationships between macroalgae, sea urchins, and predators of sea urchins are commonly reported and are often regarded as having major roles in the determination of benthic community structure (reviewed by Lawrence 1975, Mann 1982, Dayton 1985, Elner \& Vadas 1990, Lobban \& Harrison 1994, Estes \& Duggins 1995). In such interactions, the sea urchins are viewed as major potential or actual consumers of macroalgae. When urchins become abundant they can dev- 
astate macroalgal communities via overgrazing, but urchins are prevented from becoming abundant by predators such as sea otters or lobsters (or by other biotic or abiotic factors; Elner \& Vadas 1990, Lobban \& Harrison 1994). Although Sterechinus neumayeri can be abundant (Pearse \& Giese 1966, Brey et al. 1995), is a major benthic consumer in McMurdo Sound (Brey et al. 1995), and does consume some macroalgae (Pearse \& Giese 1966, McClintock 1994), it is prevented from overgrazing Phyllophora antarctica and Iridaea cordata by chemical defenses (Amsler et al. 1998). Furthermore, not only are the macroalgae ungrazed, but the urchin covering behavior directly benefits the macroalgae because large numbers of fertile plants are retained in the photic zone. Although some macroalgal species may benefit indirectly from sea urchin feeding behaviors when their macroalgal competitors are preferentially grazed (e.g. Leighton 1971 , Vadas 1977, Estes \& Duggins 1995), we are not aware of any other examples of a macroalgal species deriving direct benefit from sea urchin behavior.

The very high ratio of urchin-cover macroalgae to attached macroalgae we observed at all sites with attached plants has also been reported for Phyllophora antarctica and another red macroalga elsewhere in Antarctica (Nakajima et al. 1982). Even though we observed somewhat lower percentages of fertility in plants used as cover relative to attached plants, the larger numbers of cover plants suggest it is virtually a certainty that, in total, they make a much greater contribution to the spore cloud than do those attached directly to the substrate. Although multiple factors influence the ultimate success of macroalgal recruitment (cf. Santelices 1990, Vadas et al. 1992), such an increase in the total number of spores available would be, at the very least, a potential advantage for successful recruitment even if other factors were predominant at particular individual sites. Relative to other macroalgae, the presence of a large local spore source is most likely to be important for maintenance of red macroalgal populations in general because of their non-motile propagules, particularly in the relatively low turbulence water columns under antarctic sea ice (cf. Amsler \& Searles 1980, Santelices 1990, Amsler et al. 1992, Norton 1992).

The macroalgae benefit not only by having large numbers of plants maintained in the photic zone but also because the urchins extend the effective depth range of the plants. In the year the present study was conducted, attached Phyllophora antarctica was abundant between 7 and $10 \mathrm{~m}$ depth but was not observed deeper at any site even though attached plants have previously been observed in abundance down to $18 \mathrm{~m}$ at Cape Evans and Granite Harbor (Miller \& Pearse 1991). The presence of large numbers of fertile plants on urchins at these depths in years when attached plants do not occur there may facilitate recolonization in years when conditions allow growth of attached plants at greater depths. Similarly, small amounts of drift macroalgae are occasionally observed at locations in McMurdo Sound where attached plants do not occur, and, when so, the drift plants are always being used as part of the cover of Sterechinus neumayeri (authors' pers. obs.). Macroalgal dispersal via drift plants, either fertile when detached or becoming fertile in the drift, is not uncommon (Santelices 1990, Amsler et al. 1992, Norton 1992). Should environmental conditions at such sites change so that they could support attached macroalgal populations (most likely due to changes in annual and interannual sea ice cover $\}_{\text {, }}$ the cover plants being held in the photic zone by $S$. neumayeri could increase the likelihood or rate of macroalgal recruitment into these areas.

We have previously described another symbiotic relationship involving chemical defense in antarctic organisms. The pelagic antarctic pteropod Clione antarctica is chemically defended from predation by fish (McClintock \& Janssen 1990, Bryan et al. 1995, Yoshida et al. 1995, McClintock \& Baker 1998). The antarctic hyperiid amphipod Hyperiella dilatata captures $C$. antarctica, and individual amphipods hold individual pteropods on their backs. The chemical defenses of the captured pteropods then also defend the amphipods from predation by fish (McClintock \& Janssen 1990, McClintock \& Baker 1998). However, in this relationship the captured pteropod ceases feeding and, presumably, this negatively impacts its nutritional state. Moreover, the amphipod is not a potential pteropod predator and physical defenses are not involved, so this symbiotic relationship is distinct from the macroalgae-urchin mutualism we describe in the present study.

Another macroalga-herbivore-carnivore relationship has recently been described between the chemically defended alga Dictyota menstrualis, the decorator crab Libinia dubia, and omnivorous fishes (Stachowicz \& Hay 1999). The decorator crabs camouflage themselves with $D$. menstrualis although they treat $D$. menstrualis as a low-priority food item. The chemically defended macroalgal camouflage in turn reduces the susceptibility of the crabs to fish predation. Although similar in many respects to the antarctic macroalgaurchin relationship, this differs most importantly in being of no apparent benefit to the macroalgae. Even though $D$. menstrualis might well remain or become fertile when used as camouflage, these plants do not appear to constitute a large percentage of the total population as we have observed with the antarctic macroalgae and, in addition, there is no evidence that the decorator crabs might help maintain the 
spatial distribution of the population over time. The macroalga-crab-fish interaction also differs from the antarctic macroalga-urchin-anemone interaction in the ways in which defenses are involved. The macroalga-crab-fish interaction does not involve physical defenses. Furthermore, D. menstrualis defends the crabs from the fish because of chemical defenses that also protect the macroalgae from being eaten by the omnivorous fish. In addition to the fact that the chemical defenses that protect the antarctic macroalgae from urchin herbivory play no apparent role in protecting the urchins from Isotealia antarctica, there is no reason to suspect that this anemone is a herbivore that the macroalgae would defend themselves against by any mechanism. In this respect, the protection that macroalgae afford Sterechinus neumayeri can be described as passive since it involves neither physiological, biochemical, nor behavioral defenses.

A similar mutualism which involves the passive defense of an invertebrate by macroalgae (and other sessile epibionts) has been described by Vance (1978). Predation by the sea star Pisaster giganteus on the clam Chama pallucida is reduced by the presence of algal and other epibionts on the clams' shells. The epibionts, which also grow on a wide variety of other substrata, reportedly derive benefit from the rough surface provided by the clams as well as because the clams live in habitats with generally lower numbers of epibiont-grazing sea urchins (Vance 1978). The epibionts appear to protect the clams by making it less likely that a sea star will recognize them as a food item (Vance 1978). Although the macroalgae used as cover by Sterechinus neumayeri probably play a similar role sometimes in preventing Isotealia antarctica from recognizing the urchins as food, the macroalgae also clearly aid in the escape of urchins that are actively being attacked by anemones, as described above. Most mutualistic interactions that involve defense differ from both the epibiont-clam-sea star and macroalga-urchin-anemone interactions in that they involve active behavioral defenses of an animal rather than passive effects of plant cover (cf. Boucher et al. 1982, Glynn 1987, Ricklefs 1990).

Although the macroalgae appear to benefit by being the preferred form of urchin cover, this benefit is only relative to a situation in which the drift plants would. wash into much deeper water or onto shore. Even though the plants on urchins retain the ability to become fertile, plants collected from urchins at the same depths ( 7 to $10 \mathrm{~m}$ ) where attached plants occur are slightly less fertile than attached plants and, compared to the attached plants, there is a significant decrease in percent fertility when plants are collected from urchins at $15 \mathrm{~m}$. Therefore, drift plants on urchins probably do not make as great a contribution to the gene pool as attached plants and if the urchins were responsible for dislodging the macroalgae from the substrate, this clearly would not represent a mutualistic relationship. However, it is very unlikely that urchins are responsible for removing the macroalgae from their rock substrate. In the relatively shallow waters where the plants occur they are dislodged by anchor ice when the sea surface is covered by land-fast ice (Dayton et al. 1969, 1970) and are dislodged by iceberg scour and wave action during periods of open water (Neushul 1965, Kauffman 1974, Dayton 1990). As noted, the macroalgae are chemically defended from being consumed by the urchins (Amsler et al. 1998). When disks cut from the live thallus of either macroalga were placed over the mouth of an urchin, the urchins rejected them very rapidly (Amsler et al. 1998), which indicates that the urchins would not dislodge plant material with their mouths as is reported for urchins and macroalgae in other systems (e.g. Leighton 1971, Mann 1973). An alternate mechanism by which an urchin might dislodge a macroalga is by tearing it from the substrate using tube feet. Although we have not made biophysical measurements of either the strength of macroalgal attachment or of the strength of urchin tube feet, our experiences with both suggest that this scenario is extremely unlikely.

Sea urchin covering behaviors are observed in a wide range of species throughout the world (cf. Lawrence 1976) and there is no reason to suspect that the behavior, in and of itself, evolved independently in Sterechinus neumayeri as a predator defense mechanism. However, it is clear that this behavior is adaptive as a defense in $S$. neumayeri and, as such, that natural selection should have favored maintenance of the behavior in populations that co-occur with Isotealia antarctica. Since the defensive compounds from macroalgae do not play a necessary role in allowing $S$. neumayeri to escape from $I$. antarctica and since hydroid colonies used as cover have previously been reported to also facilitate escape (Dayton et al. 1970), we can only speculate on why $S$, neumayeri prefers macroalgae over other forms of cover. Population densities of $I$. antarctica can commonly be quite high (authors' pers. obs.) so an urchin that escaped one anemone could quickly encounter another. Since $I$. antarctica sometimes releases the macroalgae before $S$. neumayeri, allowing the urchins to both escape and retain their cover, macroalgal cover would clearly be preferable to a cover of something that the anemone would recognize as a prey item and not release. Our experience in removing finely branching hydroid colonies from urchins in laboratory preference experiments indicated that they often become entangled in an urchin's spines and, therefore, may not be as quickly or completely released as macroalgae. Finally, the flexible 
and relatively light macroalgae may have hydrodynamic or weight benefits relative to rocks, shells, or other abiotic materials which, like macroalgae, would be released by $I$. antarctica.

Phyllophora antarctica, Iridaea cordata, and Sterechinus neumayeri all have circumpolar distributions in Antarctica (Neushul 1968, Moe \& DeLaca 1976, Brey et al. 1995, and references therein). Consequently, the mutualistic relationship between them is unlikely to be restricted to McMurdo Sound. P. antarctica and I. cordata are the only fleshy macroalgae throughout most of the year in McMurdo Sound $\left(77^{\circ} \mathrm{S}\right)$ and remain as dominant members of the flora with $S$. neumayeri also abundant at least as far north as $74^{\circ} \mathrm{S}$ in the Ross Sea (Zaneveld 1966, 1968, Miller \& Pearse 1991, Gambi et al. 1994). With the exception of the most northern latitudes in Antarctica along the Antarctic Peninsula where anchor ice does not dislodge organisms in shallow water and where macroalgal species richness and total biomass are often very high (Amsler et al. 1995 and references therein), relatively little is known about the macroalgal flora along most of the rest of the antarctic coast. However, communities dominated by $P$. antarctica and $S$. neumayeri or where they are at least major components of the flora and fauna are reported throughout much of the rest of the continent including the Halswell Islands $\left(66^{\circ} \mathrm{S}, 93^{\circ} \mathrm{E}\right.$; Propp 1970), the Vesfold Hills $\left(78^{\circ} \mathrm{S}, 68^{\circ} \mathrm{E}\right.$; Dhargalkar et al. 1988, Kirkwood \& Burton 1988), and East Ongul Island $\left(69^{\circ} \mathrm{S}, 39^{\circ} \mathrm{E}\right.$; Nakajima et al. 1982). Anchor ice has a major impact in the shallow regions where macroalgae occur in McMurdo Sound (Dayton et al. 1969,1970) as well as along much if not most of the antarctic coast (Kirkwood \& Burton 1988, Knox 1994, and references therein). Anchor ice is probably responsible for most of the large amounts of macroalgal drift we observed in McMurdo Sound. It is likely that benthic communities along most of the antarctic coast are more similar to the $P$. antarctica/I. cordatadominated and anchor-ice-disturbed Ross Sea benthos than to the species-rich and less-disturbed Antarctic Peninsula benthos (Knox 1994). Thus the mutualistic interaction between macroalgae and urchins is likely to be important in maintaining macroalgal populations along most of the antarctic coastline.

Acknowledgements. We are grateful to C. Moeller, A. Marsh, R. Aronson, E. Kitzing, S. Kim, and to the employees and subcontractors of Antarctic Support Associates for assistance in the field. We thank N. Wu for the photograph in Fig. 4, R. Angus for assistance with statistics, M. Hay for communications about in press results, and $\mathrm{M}$. Amsler, K. Marion, S. Watts, and 3 anonymous reviewers for constructive comments on the manuscript. This work was supported by grants OPP9530735 and OPP-9526610 from the National Science Foundation.

\section{LITERATURE CITED}

Amsler CD, Searles RB (1980) Vertical distribution of seaweed spores in a water column offshore of North Carolina. J Phycol 16:617-619

Amsler CD, Reed DC, Neushul M (1992) The microclimate inhabited by macroalgal propagules. $\mathrm{Br}$ Phycol J 27: 253-270

Amsler CD, Rowley RJ, Lãur DR, Quetin LB, Ross RMi (1995) Vertical distribution of Antarctic peninsular macroalgae: cover, biomass, and species composition. Phycologia 34: $424-430$

Amsler CD, McClintock JB, Baker BJ (1998) Chemical defense against herbivory in the antarctic marine macroalgae Iridaea cordata and Phyllophora antarctica (Rhodophyceae). J Phycol 34:53-59

Boucher DH, James S, Keeler KH (1982) The ecology of mutualism. Annu Rev Ecol Syst 13:315-347

Brey T, Pearse J, Basch L, McClintock J, Slattery M (1995) Growth and production of Sterechinus neumayeri (Echinoidea: Echinodermata) in McMurdo Sound, Antarctica. Mar Biol 124:279-292

Bronstein JL (1994) Our current understanding of mutualism. Q Rev Biol 69:31-51

Bryan PJ, Yoshida WY, McClintock JB, Baker BJ (1995) An ecological role for pteroenone, a novel antifeedant produced by the conspicuous antarctic pteropod Clione antarctica (Gymnosomata: Gastropoda). Mar Biol 122: $271-278$

Dayton PK (1985) Ecology of kelp communities. Annu Rev Ecol Syst 16:215-245

Dayton PK (1990) Polar benthos. In: Smith WO Jr (ed) Polar oceanography, part B: chemistry, biology, and geology. Academic Press, New York, p 631-685

Dayton PK, Robilliard GA, DeVries AL (1969) Anchor ice formation in McMurdo Sound, Antarctica, and its biological effects. Science 163:273-275

Dayton PK, Robilliard GA, Paine RT (1970) Benthic faunal zonation as a result of anchor ice at McMurdo Sound, Antarctica. In: Holgate WM (ed) Antarctic ecology. Academic Press, London, p 244-258

Dhargalkar VK, Burton HR, Kirkwood JM (1988) Animal associations with the dominant species of shallow water macrophytes along the coastline of the Vesfold Hills, Antarctica. Hydrobiologia 165:141-150

Eisner T, Meinwald J (1995) Chemical ecology: the chemistry of biotic interaction. National Academy Press, Washington, $\mathrm{DC}$

Elner RW, Vadas RL Jr (1990) Inference in ecology: the sea urchin phenomenon in the northwest Atlantic. Am Nat 136:108-125

Endler JA (1986) Defense against predators. In: Feder ME, Lauder G (eds) Predator-prey relationships. Perspectives and approaches from the study of lower vertebrates. University of Chicago Press, Chicago, p 109-134

Estes JA, Duggins DO (1995) Sea otter and kelp forests in Alaska: generality and variation in a community ecological paradigm. Ecol Monogr 65:75-100

Faulkner DJ (1998) Marine natural products. Nat Prod Rep 15 $113-158$

Gambi MC, Lorenti M, Russo GF, Scipione MB (1994) Benthic associations of the shallow hard bottoms off Terra Nova Bay, Ross Sea: zonation, biomass and popluation structure. Antarct Sci 6:449-462

Glynn PW (1987) Some ecological consequences of coralcrustacean guard mutualisms in the Indian and Pacific Oceans. Symbiosis 4:301-324 
Harvell CD (1984) Predator-induced defense in a marine bryozoan. Science 224:1357-1359

Hay ME (1996) Marine chemical ecology: what's known and what's next? J Exp Mar Biol Ecol 200:103-134

Hay ME, Kappel QE, Fenical W (1994) Synergisims in plant defenses against herbivores: interactions of chemsitry, calcification, and plant quality. Ecology 75:1714-1726

Kauffman TA (1974) Seasonality and disturbance in benthic communities, Arthur Harbor, Antarctic Peninsula. Antarct J US 9:307-310

Kirkwood JM, Burton HR (1988) Macrobenthic assemblages in Ellis Fjord, Vesfold Hills, Antarctica. Mar Biol 97: $445-457$

Knox GA (1994) The biology of the Southern Ocean. Cambridge Univ Press, Cambridge

Lawrence JM (1975) On the relationships between marine plants and sea urchins. Oceanogr Mar Biol Annu Rev 13: 213-286

Lawrence JM (1976) Covering response in sea urchins. Nature 262:490

Leighton DL (1971) Grazing activities of benthic invertebrates in Southern California kelp beds. Nova Hedwigia 32: $421-453$

Lobban CS, Harrison PJ (1994) Seaweed ecology and physiology. Cambridge Univ Press, Cambridge

Mann KH (1973) Seaweeds: their productivity and strategy for growth. Science 182:975-981

Mann KH (1982) Ecology of coastal waters. A systems approach. Univ of California Press, Berkeley

Mauricio R, Rausher MD (1997) Experimental manipulation of putative selective agents provides evidence for the role of natural enemies in the evolution of plant defense. Evolution 51:1435-1444

McClintock JB (1994) Trophic biology of antarctic echinoderms. Mar Ecol Prog Ser 111:191-202

McClintock JB, Baker BJ (1997a) A review of the chemical ecology of shallow-water antarctic marine invertebrates. Am Zool 37:329-342

McClintock JB, Baker BJ (1997b) Palatability and chemical defense in the eggs, embryos and larvae of shallow-water antarctic marine invertebrates. Mar Ecol Prog Ser 154: $121-131$

McClintock JB, Baker BJ (1998) Chemical ecology in Antarctic seas. Am Sci 86:254-263

McClintock JB, Janssen J (1990) Pteropod abduction as a chemical defense in a pelagic antarctic amphipod. Nature 346:424-426

Miller KA, Pearse JS (1991) Ecological studies of seaweeds in McMurdo Sound, Antarctica. Am Zool 31:35-48

Moe RL, DeLaca TE (1976) Occurrence of macroscopic algae along the Antarctic Peninsula. Antarct J US 11:20-24

Myers JH, Brazely D (1991) Thorns, spines, prickles, and hairs: are they stimulated by herbivory and do they deter herbivores? In: Tallamy DW, Raypp MJ (eds) Phytochemical induction by herbivores. John Wiley \& Sons, New York, p 325-344

Nakajima Y, Watanabe K, Naito Y (1982) Diving observations

Editorial responsibility: Joseph Pawlik (Contributing Editor), Wilmington, North Carolina, USA of the marine benthos at Syowa Station, Antarctica. In: Hoshia T, Naito Y (eds) Proceedings of the fifth symposium on antarctic biology. Memoirs of National Institute of Polar Research Special Issue 23. National Institute of. Polar Research, Tokyo, p 44-54

Neushul M (1965) Diving observation of sub-tidal Antarctic marine vegetation. Bot Mar 8:234-243

Neushul M (1968) Benthic marine algae. Antarct Map Folio Ser 10:9-10

Norton TA (1992) Dispersal by macroalgae. Br Phycol J 27 $293-301$

Paul VJ (1992) Ecological roles of marine natural products Cornell Univ Press, Ithaca

Pawlik JR (1993) Marine invertebrate chemical defenses Chem Rev 93:1911-1922

Pearse JS, Giese AC (1966) Food, reproduction and organic constitution of the common antarctic echinoid Sterechinus neumayeri (Meissner). Biol Bull 130:387-401

Propp MV (1970) The study of the bottom fauna at Halswell Islands bu scuba diving. In: Holgate WM (ed) Antarctic ecology. Academic Press, London, p 239-241

Ricklefs RE (1990) Ecology, 3rd edn. WH Freeman and Company, New York

Roitberg BD, Isman MB (1992) Insect chemical ecology Chapman \& Hall, New York

Santelices B (1990) Patterns of reproduction, dispersal and recruitment in seaweeds. Oceanogr Mar Biol Annu Rev 28:177-276

Schupp PJ, Paul VJ (1994) Calcification and secondary metabolites in tropical seaweeds: variable effects on herbivorous fishes. Ecology 75:1172-1185

Stachowicz JJ, Hay ME (1999) Reducing predation theough chemically-mediated camouflage: indirect effects of plant defenses on herbivores. Ecology 80:495-509

Steneck RS, Watling L (1982) Feeding capabilities and limitation of herbivorous molluscs: a functional approach. Mar Biol 68:299-312

Vadas RL (1977) Preferential feeding: an optimization strategy in sea urchins. Ecol Monogr 47:337-371

Vadas RL, Johnson S, Norton TA (1992) Recruitment and mortality of early post-settlement stages of benthic algae. $\mathrm{Br}$ Phycol J 27:331-351

Vance RR (1978) A mutualistic interaction between a sessile marine clam and its epibionts. Ecology 59:679-685

Vitt LJ (1983) Tail loss in Lizards: the significance of foraging and predator escape modes. Herpetologica 39:151-162

Yoshida W, Bryan P, Baker BJ, McClintock JB (1995) Pteroenone: a defensive metabolite of the abducted antarctic pteropod Clione antarctica. J Org Chem 60 $780-782$

Zaneveld JS (1966) The occurrence of benthic marine algae under shore fast-ice in the western Ross Sea. Antarctica Proc Int Seaweed Symp 5:217-231

Zaneveld JS (1968) Benthic marine algae, Ross Island to the Balleny Islands. Antarct Map Folio Ser 10:10-12

Zar JH (1984) Biostatistical analysis, 2nd edn. Prentice-Hall, Inc, Englewood Cliffs, NJ

Submitted: October 2, 1998; Accepted: February 15, 1999

Proofs received from author(s): June 7, 1999 